\title{
Proactive personality and career decision self-efficacy: The mediating role of planned happenstance
}

\author{
Felinsa Oktora Tanau ${ }^{1}$, Rose Mini Agoes Salim² \\ 1,2 Faculty of Psychology, Universitas Indonesia, Indonesia \\ ${ }^{1}$ felinsatanau@gmail.com; ${ }^{2}$ romy.prianto@gmail.com
}

\section{ARTICLE INFO}

Article history

Received 31 July 2019

Revised 7 April 2020

Accepted 30 April 2020

Keywords

career decision self-efficacy junior high school students planned happenstance proactive personality

\begin{abstract}
The junior high school major decision, influenced by personality and capacity, has a subsequent impact on the future careers of the students. This study aimed to identify the mediating role of planned happenstance in the relationship between proactive personality and career decision self-efficacy in junior high school students. As many as 140 junior high school students in Jabodetabek with an average age of 14 years participated in this study. They mainly consist of 9thgrade students ( 88 females and 52 males). This quantitative study used a non-experimental design, namely the cross-sectional study design. Three adapted measurement tools: career decision selfefficacy short form, proactive personality scale, and planned happenstance career inventory were used to collect the data. Data were analyzed using Haye's regression techniques to test the mediation. The finding supports the hypothesis, that planned happenstance partially mediates the relationship between proactive personality and career decision self-efficacy. In other words, proactive personality could influence students' planned happenstance, which ultimately could predict their level of selfefficacy in making career decisions. The implications of the results for the development and preparation for junior high school students are discussed.
\end{abstract}

\section{Introduction}

The Indonesian education system requires children to attend school for a minimum of 9 years - junior high school level (Constitution No. 20 the Year 2003). After this level, students are free to make their own decisions, whether to continue to high school or not. Students who decide to continue with the school must choose between enrolling in a general or vocational high school, highlighting that students must prepare, consider, and decide on their career direction during this stage. According to Urbanaviciute et al. (2017), this early school decision could affect the students' future careers.

Choosing and deciding on future work largely depends on the decision-making process in junior high school (Germeijs et al., 2012). Individuals might encounter difficulties and doubt in making that decision because it is considered to be a long-term commitment (Germeijs et al., 2012; Urbanaviciute et al., 2017). The decision-making process is quite complicated because students must explore various alternative career choices, reflect on their interest and capacity, compare alternative career choices following their ability, before finally determining the final decision (Garcia et al., 2015; Germeijs et al., 2012). According to Lee, Song, \& Kim (2018), designing career is a significant step in life and may lead to anxiety (Jiang, 2014; Jung, Park, \& Rie, 2015). 
Self-efficacy becomes an essential factor in making career decisions, often referred to as Career Decisions Self-Efficacy (CDSE) (Bandura, 1995; Garcia et al., 2015; Germeijs et al., 2012; Jiang, 2014). CDSE also encourages individuals to engage in certain behaviors in career decision-making processes related to self-assessment, gathering work information, solving problems, choosing goals, and planning for the future (Jiang, 2014; Jiang, 2015; Lee et al., 2018; Shin \& Lee, 2016). According to Lee et al. (2018), students who lack confidence in their planned career path face several problems such as a decrease in academic achievement, mismatch in social and family life, which can ultimately lead to failure in achieving education high. Thus, having confidence aid in supporting students' career decision-making process.

The family (i.e., parents, socioeconomic status) could influence students' career decisions (Bakker, Tims, \& Derks, 2012; Hsieh \& Huang, 2014; McCromick, Guay, Colbert, \& Stewart, 2018). However, internal factors have been noted to have more influence compared to external factors when it comes to controlling particular situations (Bakker et al., 2012). Among these factors, a proactive personality affects CDSE higher than the family's socioeconomic status (Hsieh \& Huang, 2014). This finding indicates that a proactive personality as a strong personal factor plays a more significant role in driving someone (Hsieh \& Huang, 2014; McCromick et al., 2018). Proactive personality is defined as a personal initiative that influences and encourages a person to take action (Bateman \& Crant, 1993; Crant, 2000; Hsieh \& Huang, 2014). Those with a proactive personality show initiative to solve problems and take advantage of the opportunities to improve their current situation (Hsieh \& Huang, 2014; McCromick et al., 2018). Bateman \& Crant (1993) noted that people with a proactive personality have high initiative, view things positively, actively work, and seek information and ways to improve their performance. Additionally, proactive people tend to have new ways of doing tasks and generate new ideas to enhance their initiatives (Crant, 2000). Having a proactive personality means someone has the initiative to improve the current situation and actively seek information and opportunities to support their performance (Crant, 2000). Furthermore, people who have proactive personalities identify opportunities and follow them up and take action (Hsieh \& Huang, 2014). Meanwhile, those who are passive tend to wait for information and opportunities to come to them (Crant, 2000). According to McCromick et al. (2018), proactive personality encourages individuals to perform actions based on their abilities.

Proactive personality is an individual's predisposition toward proactive behaviors that could bring meaningful changes to the environment (Jiang, 2017). Bakker et al. (2012) asserted that individuals with a proactive personality identify opportunities, take action, and persevere until significant outcomes in their life could be attained. Therefore individuals are able to detect, act on career opportunities and create work environments that fit with their vocational interests, as a result, they will be more likely to be well prepared for changes in the vocation (Jiang, 2017). According to Valickas, Raisiene, \& Rapuano (2019), in a work setting, individuals who pursue successful and meaningful careers must adjust to various changes in the environment. Unpredictable situations will always influence career development, highlighting the importance of having the skills to adapt to various sudden changes (Eissenstat \& Nadermann, 2018; Urbanaviciute et al., 2017). This skill is referred to as planned happenstance, which considers an unexpected event as a learning experience that can be chosen to act on an unplanned event (Kim, et al., 2017; Urbanaviciute et al., 2017; Valickas et al., 2019).

Having the planned happenstance skills could help students in carrying out a career with job possibilities and demands that cannot be predicted (Kim et al., 2017). Additionally, according to Ahn et al. (2015), having these skills would enable students to explore, act, learn and benefit from unplanned events. Mitchell et al. (1999) stated that people who have planned happenstance skills have high curiosity are persistent, flexible, optimistic, and dare to take risks on careers and contribute to CDSE improvement (Kim et al., 2017). 
Valickas et al. (2019) stated planned happenstance allows students to manage daily problems and design brilliant careers, highlighting its' benefit to one's future careers. Students who can transform unpredictable conditions into opportunities will gain more opportunities and experiences that enhance their career potentials (Eissenstat \& Nadermann, 2018; Kim et al., 2019).

Currently, no one has yet investigated how proactive personality encourages the emergence of planned happenstance. The current researchers assume that individual who has proactive personality will use their skills to manage daily problems and perceive them as added experience that could be useful for their future career. Investigating these variables could provide new and alternative knowledge for psychologists or career counselors for future intervention to fit the demands of students from different backgrounds. However, the theory shows that having a proactive personality drives actions that are likely based on the skills of the students to manage the conditions (McCromick et al., 2018). Individuals with a proactive personality deliberately control the power from within themselves to change a situation or environment, identify opportunities, take advantage of opportunities, take action, and persevere until meaningful changes are achieved (Bakker et al., 2012; Crant, 2000; Hsieh \& Huang, 2014; McCromick et al., 2018). Thus, a proactive personality is expected to build planned happenstance. Planned happenstance is expected to help increase self-efficacy in making career decisions. Planned happenstance is expected to increase personal initiative that encourages a person to take action and make career decisions. Based on these considerations, the current study proposes the following hypothesis: planned happenstance plays a significant role in partially mediating the influence of proactive personality towards CDSE among junior high school students.

\section{Method}

This current research is a quantitative non-experimental, cross-sectional study. Before participating in this study, participants got information on the purpose of the study and completed the informed consent under the parents' supervision.

\section{Research Participant}

One hundred and forty junior high school students in Jabodetabek participated in this study. There were 88 female students and 52 male students with an average age of 14 years. The students were mostly 9 th-grade students.

\section{Measurement}

Online questionnaires were distributed through several teachers in the Greater Jakarta area randomly and received as many as 140 students who first filled out informed consent. The questionnaires take 15 to 20 minutes to complete. No participants were excluded because they all met the inclusive criteria and completed the form with no missing items.

Self-efficacy in the career decision-making process is measured by the adapted version of the Career Decision Self-Efficacy Short Form (CDSE-SF) by Sawitri (2008) based on Betz, Voyten, \& Klein (1997) CDSE scale. The CDSE-SF scale consists of 25 statements with a 6-point Likert scale, starting from Very Unsure (VU) to Very Sure (VS). The CDSE-SF scale in this study has a Cronbach's alpha of .914 and item discriminating index ranging from .317 to .685 .

Planned Happenstance Career Inventory (PHCI) is a scale developed by Kim et al. (2014) based on the theory developed by Mitchell et al. (1999). PHCI has five subscales, namely curiosity, perseverance, flexibility, optimism, and risk-taking. There are five items for each subscale, rated on a 5-point Likert scale starting from 1 (Totally disagree) to 5 (Strongly agree). After going through the process of adaptation, back-to-back translation, 
and expert judgment test by a lecturer at the Faculty of Psychology, Universitas Indonesia, a tryout process was carried out on junior high school students. The scale achieved a Cronbach's alpha of .917 with item discriminating index ranging from .370 to .705.

The Proactive Personality Scale (PPS) is a scale developed by Seibert et al. (1999) based on Bateman \& Crant (1993). The PPS consists of ten short-form items based on Bateman \& Crant (1993), which previously consisted of 17 items. The PPS is a 6-point Likert scale, ranging from Strongly Disagree to Strongly Agree. After the adaptation is carried out, through back-to-back translation and expert judgment tests by a lecturer at the Faculty of Psychology, Universitas Indonesia, a tryout process is carried out on junior high school students. This measurement tool achieved a Cronbach's alpha of .788 with item discriminating index ranged from .325 to 0.558 . Table 1 shows the three scales used in this study.

Table 1

Scales in the Study

\begin{tabular}{|c|c|c|c|}
\hline Scale & $\begin{array}{l}\text { Number } \\
\text { of items }\end{array}$ & $\begin{array}{l}\text { Cronbach's } \\
\text { Alpha }\end{array}$ & Example of items \\
\hline $\begin{array}{l}\text { Self-Efficacy Short Form } \\
\text { (CDSE-SF) }\end{array}$ & 25 & .914 & $\begin{array}{l}\text { Determine the ideal job for me, Very unsure (1) } \\
\text { - Sure (6) }\end{array}$ \\
\hline $\begin{array}{l}\text { Planned Happenstance Career } \\
\text { Inventory (PHCI) }\end{array}$ & 25 & .917 & $\begin{array}{l}\text { There will be many career opportunities in my } \\
\text { future, strongly agree (1) - strongly disagree } \\
\text { (6) }\end{array}$ \\
\hline $\begin{array}{l}\text { Proactive Personality Scale } \\
\text { (PPS) }\end{array}$ & 10 & .788 & $\begin{array}{l}\text { I am constantly on the lookout for new ways to } \\
\text { improve my life, strongly agree (1) - strongly } \\
\text { disagree ( } 7)\end{array}$ \\
\hline
\end{tabular}

\section{Data Analysis}

The regression analysis technique to test the mediation uses Hayes Macro PROCESS v3.3 Andrew F. Hayes model 4 was applied in this study. The statistical analysis was performed using IBM SPSS Statistics 23.

\section{Results}

The correlation analysis reveals that proactive personality and planned happenstance are positively and significantly $(\mathrm{r}=.678, \mathrm{p}=.000)$. This result indicates that junior high school students with the higher score in proactive personality showed more significant skills in taking advantage of existing career opportunities. Planned happenstance also correlates positively and significantly with CDSE $(r=.694, \mathrm{p}=.000)$, indicating that higher scores in planned happenstance relate to a higher level of career decision self-efficacy. Table 2 depicts the correlation matrix between variables.

Table 2

Correlation Matrix

\begin{tabular}{|c|c|c|c|c|c|c|}
\hline & & 1 & 2 & 3 & $M$ & $S D$ \\
\hline 1. & PP & - & & & 5.03 & .584 \\
\hline 2. & PHS & $.678^{* *}$ & - & & 5.01 & .586 \\
\hline 3. & CDSE & $.573 * *$ & $.694 * *$ & - & 4.78 & 677 \\
\hline $\begin{array}{l}\mathrm{PP} \\
\mathrm{Se} \\
* *\end{array}$ & $\begin{array}{l}\text { active } \\
\text { acy }\end{array}$ & lity; $\mathrm{PH}$ & $=$ Plan & $p l$ & $\mathrm{CDS}$ & Decisions \\
\hline
\end{tabular}


The regression test using Macro Hayes PROCESS v3.3, as shown in Figure 1, indicates that proactive personality has a significant relationship to career decision selfefficacy $\left(c^{\prime}=.220, p=.001\right)$. This result implies that proactive personality has a significant effect on career decision self-efficacy.

Additionally, proactive personality was also found to have a significant influence on planned happenstance $(\mathrm{a}=.680, p=.000)$, while planned happenstance significantly influences career decision self-efficacy $(\mathrm{b}=.653, p=.001)$. This result implies that proactive personality encourages the emergence of planned happenstance that ultimately leads to greater career decision self-efficacy. The indirect effect that showed proactive personality on career decision self-efficacy occurred significantly $(\mathrm{ab}=.442, p=.000)$.

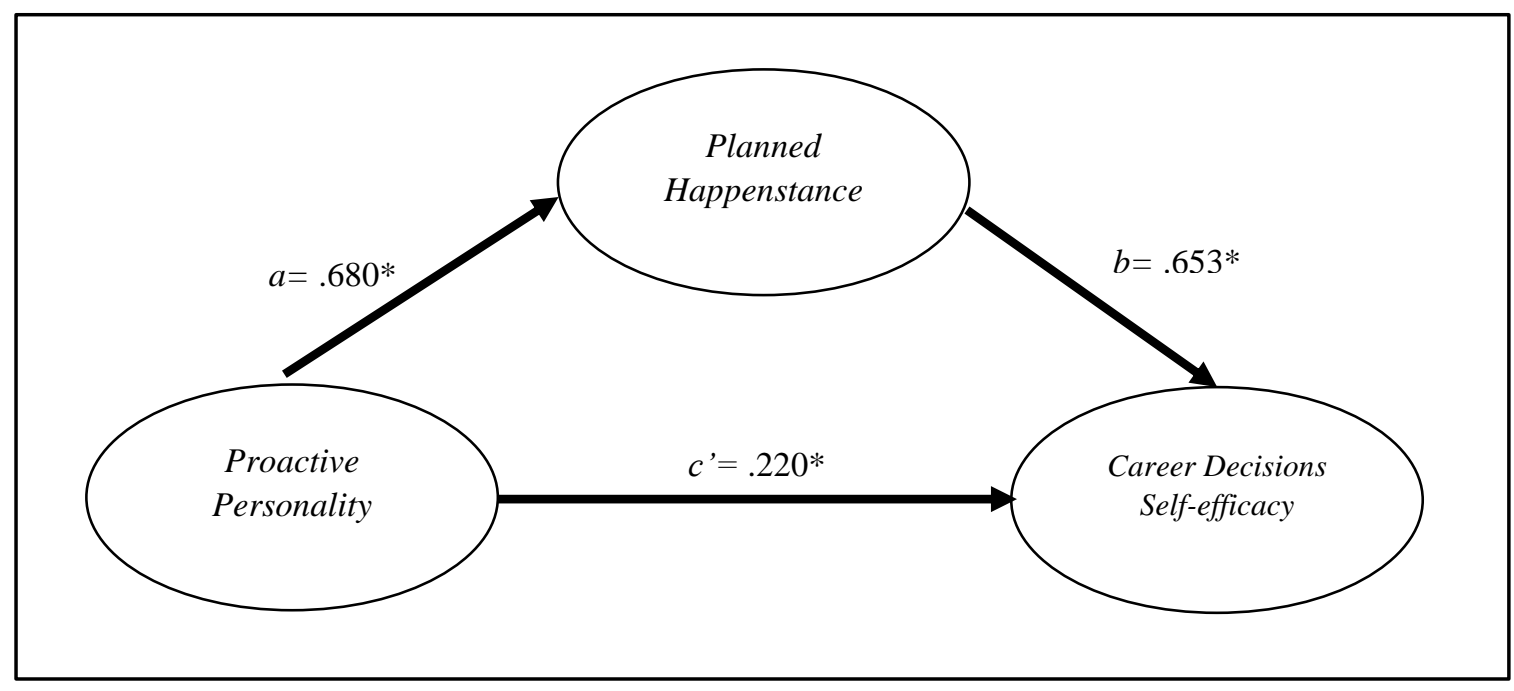

Figure 1. Planned happenstance mediates the relationship of proactive personality and career decision self-efficacy

Planned happenstance significantly partially mediates the relationship between proactive personality and CDSE. The indirect effect of proactive personality on CDSE mediated by planned happenstance is greater than the direct effect. Thus, planned happenstance influences the effect of proactive personality towards CDSE. Based on the result, the research hypothesis that planned happenstance partially mediates the relationship between proactive personality and CDSE is accepted.

\section{Discussion}

Planned happenstance partially mediates the relationship between proactive personality and CDSE. This result indicates proactive personality encourages the development of planned happenstance, thereby affecting the increase in CDSE. This result provides a novel understanding of planned happenstance as a mediator of proactive personality and CDSE.

Proactive personality affects CDSE directly. Proactive personality creates conducive conditions for personal success; hence, these individuals' initiatives may enhance confidence in their CDSE H. S. Kim \& Park (2017). Hsieh \& Huang (2014) claims that individuals with high proactive personalities are relatively unrestricted by situational forces and have a greater sense of self-efficacy in their career lives.

However, the indirect effect is higher than the direct effect. The relationship between proactive personality and CDSE is stronger when planned happenstance act as a partial mediator. This finding confirms previous research conducted by McCromick et al. (2018), which concluded that people with a more proactive personality has the skill to transform 
unplanned conditions into an opportunity to improve their performance. Many factors influence individuals to change their minds Kim et al. (2019), especially junior high school students who are still in the process of designing their future. As such, individuals with a proactive personality will deliberately control their internal power to change a situation or environment, identify opportunities, take advantage of opportunities, take action, and persevere until they could achieve meaningful changes (Bakker et al., 2012; Crant, 2000; Hsieh \& Huang, 2014; McCromick et al., 2018). Individuals with planned happenstance skills could adapt more quickly and regard unexpected conditions as opportunities. This situation would help them build planned happenstance, which would benefit them by increasing their self-efficacy in making career decisions.

The results of the regression tests indicate that planned happenstance significantly influences the effect of proactive personality towards CDSE. Kim et al. (2019) demonstrated that having planned happenstance skills provide opportunities to obtain career choices that allowed people to make, take, support, and get opportunities in any need for improvement. Furthermore, planned happenstance skills help individuals achieve career-associated opportunities from new experiences by transforming happenstance events into opportunities, and in turn, contribute to career decision self-efficacy (Kim et al., 2016). The current finding that highlights planned happenstance's role as a partial mediator is in line with McCromick et al. (2018), who stated the importance of skill to set requirements, but proactive personality is the primary role in encouraging one's success in obtaining positive results such as satisfaction and career success, job satisfaction, and organizational commitment.

By having a proactive personality will improve the planned happenstance skill in increasing one's career decision self-efficacy. Proactive personality is the main factor that increases one's skill (McCromick et al., 2018). A person's personality will encourage the skills to use opportunities for unexpected events as opportunities for assistance appropriately. Also, having a proactive personality drives someone to innovate, new ways and ideas to run entirely (Jafri, Dem, \& Choden, 2016). However, Urbanaviciute et al. (2017) decided that career selection is a complicated process, skills needed to be prepared early to facilitate careers those developed that connect junior high school individuals to find works. Thus, developing a proactive personality and increasing the planned happenstance will help a person improve career decision self-efficacy for the future. It would be beneficial for adolescents, particularly those involved in this research, to identify and develop their level of proactive personality. This action would sharpen their planned happenstance skills which could increase their confidence in making career choices. That will be very useful for them who are indeed in a period of looking for identity, exploration, and educational performance (Lannegrand-Willems, Perchec, \& Marchal, 2016). Additionally, these skills could also help young people to manage and adjust to the changes that they will surely experience (Valickas et al., 2019) and increase career decision self-efficacy.

This study identifies proactive personality and planned happenstance as internal factors that are influencing the Career Decisions Self-efficacy among junior high school students. However, researchers realize that junior high school students are inseparable from the involvement of parents. For this reason, future studies are advised to investigate the influence of parents in the formation of proactive personalities or in developing planned happenstance. Researchers acknowledge that other potential supporting factors need to be explored in future studies, which is not explained in this study, such as parental involvement. 


\section{Conclusion}

This study concludes that planned happenstance partially mediated the relationship of proactive personality and CDSE among junior high school students. Proactive personality has a more significant impact on CSDE if mediated by planned happenstance. Even though proactive personality directly influences CDSE, but with planned happenstance skills, the improvement will be greater. Developing a proactive personality in junior high school students will significantly increase their expertise to establish planned happenstance. These skills will enhance self-efficacy in making career decisions because students have more extensive career choices. Therefore, planned happenstance has an important role in improving the CDSE of junior high school students.

\section{References}

Ahn, S., Jung, S. H., Jang, S. H., Du, X., Lee, B. H., Rhee, E., \& Lee, S. M. (2015). Planned happenstance skills and occupational identity status in high school students. The Career Development Quarterly, 63(1), 31-43. https://doi.org/10.1002/j.21610045.2015.00093.x

Bakker, A. B., Tims, M., \& Derks, D. (2012). Proactive personality and job performance: The role of job crafting and work engagement. Human Relations, 65(10), 1359-1378. https://doi.org/10.1177/0018726712453471

Bandura, A. (1995). Self-efficacy in changing societies. Cambridge: Cambridge University Press.

Bateman, T. S., \& Crant, J. M. (1993). The proactive component of organizational behavior: A measure and correlates. Journal of Organizational Behavior, 14(2), 103-118. https://doi.org/10.1002/job.4030140202

Betz, N. E., Voyten, K., \& Klein. (1997). Efficacy and outcome expectations influence career exploration and decidedness. The Career Development Quarterly, 46(2), 179189. https://doi.org/10.1002/j.2161-0045.1997.tb01004.x

Crant, J. M. (2000). Proactive behavior in organizations. Journal of Management, 26(3), 435-462. https://doi.org/10.1177/014920630002600304

Eissenstat, S. J., \& Nadermann, K. (2018). Examining the use of planned happenstance with students of Korean cultural backgrounds in the United States. Journal of Career Development, 46(4), 455-468. https://doi.org/10.1177/0894845318763955

Garcia, P. R. J. M., Restubog, S. L. D., Bordia, Prashant, B., Sabari, B., \& Roxas, R. E. O. (2015). Career optimism: The roles of contextual support and career decision-making self-efficacy. Journal of Vocational Behavior, 88, 10-18. https://doi.org/10.1016/j.jvb.2015.02.004

Germeijs, V., Luyckx, K., Notelaers, G., Goossens, L., \& Vershuere, K. (2012). Choosing a major in higher education: Profiles of students' decision-making process. Contemporary Educational Psychology, 37(3), 229-239. https://doi.org/10.1016/j.cedpsych.2011.12.002

Hayes, A. F. (2013). Introduction to mediation, moderation, and conditional process analysis. New York: The Guildford Press.

Hsieh, H., \& Huang, J. (2014). The effects of socioeconomic status and proactive personality on career decision self-efficacy. The Career Development Quarterly, 62(1), 29-43. https://doi.org/10.1002/j.2161-0045.2014.00068.x

Jafri, M. H., Dem, C., \& Choden, S. (2016). Emotional intelligence and employee creativity: 
Moderating role of proactive personality and organizational climate. Business Perspectives and Research, 4(1), 54-66. https://doi.org/10.1177/2278533715605435

Jiang, Z. (2014). Emotional intelligence and career decision-making self-efficacy: National and gender differences. Journal of Employment Counseling, 51(3), 112-124. https://doi.org/10.1002/j.2161-1920.2014.00046.x

Jiang, Z. (2015). Core self-evaluation and career decision self-efficacy: A mediation model of value orientations. Personality and Individual Differences, 86, 450-454. https://doi.org/10.1016/j.paid.2015.07.012

Jiang, Z. (2017). Proactive personality and career adaptability: The role of thriving at work. Journal of Vocational Behavior 98, 85-97, 98, 85-97. https://doi.org/10.1016/j.jvb.2016.10.003

Jung, H., Park, I., \& Rie, J. (2015). Future time perspective and career decisions: The moderating effects of affect spin. Journal of Vocational Behavior, 89, 46-55. https://doi.org/10.1016/j.jvb.2015.04.010

Kim, B., Jung, S. H., Jang, S. H., Lee, B., Rhee, E., Cho, S. H., \& Lee, S. M. (2014). Construction and initial validation of the Planned Happenstance Career Inventory. The Career Development Quarterly, 62(3), 239-253. https://doi.org/10.1002/j.21610045.2014.00082.x

Kim, B., Rhee, E., Ha, G., Yang, J., \& Lee, S. M. (2016). Tolerance of uncertainty: Links to happenstance, career decision self-efficacy, and career satisfaction. Journal of The Career Development Quarterly, 64(2), 140-152. https://doi.org/10.1002/cdq.12047

Kim, H. S., \& Park, I. (2017). Influence of proactive personality on career self-efficacy. Journal of Employment Counseling, 54(4), 168-182. https://doi.org/10.1002/joec.12065

Kim, N., Jang, S. Y., \& Baek, P. (2019). Career chance experience of Korean women workers. Career Development International, 24(1), 74-90. https://doi.org/10.1108/CDI-04-2018-0108

Kim, S. R., Kim, B., Yang, N., Yaung, H., \& Lee, S. M. (2017). Longitudinal changes of planned happenstance skills by gender, community types, and employment status in a sample of college students in school-to-work transition. Journal of Employment Counseling, 54(4), 183-191. https://doi.org/10.1002/joec.12066

Lannegrand-Willems, L., Perchec, C., \& Marchal, C. (2016). Vocational identity and psychological adjustment: A study in French adolescents and emerging adults. Journal of Adolescence, 47, 210-219. https://doi.org/10.1016/j.adolescence.2015.10.005

Lee, J., Song, K., \& Kim, D. (2018). Self-efficacy, attribution, and adjustment to college life. North American Journal of Psychology, 20(3), 575-600.

McCromick, B. W., Guay, R. P., Colbert, A. E., \& Stewart, G. L. (2018). Proactive personality and proactive behaviour: Perspectives on person-situation interactions. Journal of Occupational and Organizational Psychology, 92(1), 30-51. https://doi.org/joop.12234

Mitchell, K. E., Levin, S. A., \& Krumboltz, J. D. (1999). Planned happenstance: Constructing unexpected career opportunities. Journal of Counseling \& Development, 77(2), 115-124. https://doi.org/10.1002/j.1556-6676.1999.tb02431.x

Pemerintah Indonesia. (2003). Undang-undang Republik Indonesia Nomor 20 Tahun 2003, tentang Sistem Pendidikan Nasional. (Law of the Republic of Indonesia Number 20 of 2003, on the National Education System). Jakarta: Sekretariat Negara.

Sawitri, D. R. (2008). Pengaruh status identitas dan efikasi diri keputusan karir terhadap keraguan mengambil keputusan karir pada siswa SMA kelas 12 (The effect of identity status and career decision self-efficacy on doubt in career decision making among 12th 
grade high school. Unpublished Master Thesis.

Seibert, S., Crant, J. M., \& Kraimer, M. L. (1999). Proactive personality and career success. Journal of Applied Psychology, 84(3), 416-427. https://doi.org/10.1037/00219010.84.3.416

Shin, Y., \& Lee, J. (2016). Attachment, career-choice pessimism, and intrinsic motivation as predictors of college students' career adaptability. Journal of Career Development, 44(4), 311-326. https://doi.org/10.1177/0894845316653472

Urbanaviciute, I., Kairys, A., Paradnike, K., \& Pociute, B. (2017). Capturing serendipity in careers: An evaluation of the Planned Happenstance Career Inventory with Lithuanian undergraduates. Journal of Career Development, 46(2), 157-170. https://doi.org/10.1177/0894845317731158

Valickas, A., Raisiene, A. G., \& Rapuano, V. (2019). Planned happenstance skills as personal resources for students' psychological wellbeing and academic adjustment. Sustainability, 11(2), 3401. https://doi.org/10.3390/su11123401 